Journal of Teacher Education for Sustainability, vol. 20, no. 1, pp. 82-92, 2018

\title{
The Need for Entrepreneurial Education at University
}

\author{
Rita Vaicekauskaite \\ Klaipeda University, Klaipeda, Lithuania \\ Asta Valackiene \\ Kaunas University of Technology, Kaunas, Lithuania
}

\begin{abstract}
Entrepreneurship has been seen as a mystical phenomenon for many years. It has been a prevalent notion about success for talented and lucky people. The growing number of research confirms that education plays a significant role in fostering entrepreneurship and new attitudes to it. Recent measurements have mainly been oriented to education as fostering motivation for business-oriented entrepreneurship; moreover, growing attention is devoted to sustainability entrepreneurship. The article introduces the conceptual analysis of different education models and generated impact on entrepreneurial activities. The article also provides an interview-based research analysis about students and teachers' early entrepreneurial intentions and activities. The present study confirms a significant need for entrepreneurial education in order to start, develop, and successfully realise innovative ideas.
\end{abstract}

Keywords: entrepreneurship, education, university

\section{Introduction}

For many years, education and scientific inquiry have been driven by the desire to discover the truth. The paradigm of innovation implied that scientists generated value in the process of their scientific research (Salite et al., 2016). Nowadays higher education has a complex task to enable knowledge to solve real problems with emergent economic effect. Evidence is rapidly growing that a great gap still existing between knowledge production and application might be successfully filled by entrepreneurship.

The meaning of entrepreneurship is narrowed to the ability to create a "business plan", to establish an enterprise, or to start a business. However, broadly defined, entrepreneurship means the ability to create wealth; it also refers to the dynamic interaction between the individual and any opportunities in a given environment marked by a high degree of complexity and uncertainty (Neck, Greene, 2011; Dutta et al., 2011). Neck and colleagues (2018) note that entrepreneurship is surrounded by myths of risk taking, moment success and young people can get wrong attitude; therefore, it is important to study early experience of successful entrepreneurs. 
Ries (2011, p. 28) notes that too often we overemphasise the significance of product (services) in entrepreneurship instead of thinking about people: "it is an acutely human enterprise". On the other hand, Christensen (2000) talking about history of the disk drive industry states, "the disruptive innovations were technologically straightforward" (p. 23).

Many experts agree that our economic future to great extent depends on entrepreneurs. Due to both reasons of extended conceptualisation and importance for society, there is a great need to find out ways to foster entrepreneurship, and the particular role is given to university. Entrepreneurship is mainly related to business establishment outside university. Corporate entrepreneurship is a way when large organisations encourage entrepreneurial spirit (Neck et al., 2018). Mathews (2012) states that we need more than just "the innovation department", we need a culture of innovation. Moreover, corporate entrepreneurship is gaining more meaningfulness when oriented to sustainability entrepreneurship.

Entrepreneurship is becoming a meaningful building block of society eco-development. It reveals growing efforts in linking entrepreneurship and sustainability (Linden, 2018). According to Hall (2010), it is substantial awareness that entrepreneurship has a unique impact on a transition to more sustainable society; however, "there remain major gaps in our knowledge of whether and how this process will actually unfold" (ibid, p. 440). Therefore, it is raising importance for conceptualisation of entrepreneurship in the perspective of sustainability.

The article introduces conceptual analysis about different education models and generated impact on entrepreneurial activities. The article embodies interview-based research and descriptive analysis about students and teachers' early entrepreneurial experiences when they had no special preparation before. Research methodology is based on naturalistic inquiry and social constructionism notion calling to move "from empiricism to constructionism" (Gergen, 2015, p. 62). Three separate group interview sessions were conducted with four university students, three university teachers, and four administration specialists who have been involved in entrepreneurial activities in recent five years. The interview is the most dominant research method in the field of entrepreneurship (Kraus, Meier, \& Niemand, 2016). We claim, that university learning environment fosters entrepreneurial initiatives with motivation for new opportunities, however, the need for entrepreneurial education rise due to challenges of complex situation for perspective development. Furthermore, combining conceptualization and descriptive research data analysis we aim to find out how the need for education is related with particular education model.

\section{Review on Research Evidence: The Role of Education in Fostering Entrepreneurship}

Entrepreneurship is a discipline, and thus it can be both learnt and taught (Kassean et al., 2015; Ries, 2011). As Ries (2011, p. 49) notes "anybody who fails in a start-up can claim that he or she has learned a lot from the experience". However, Cope (2011) remarks that the process of learning from failure is not clearly described and conceptualised. Laukkanen (2000) suggests differentiating between "educate entrepreneurship" and "teach entrepreneurship". Teaching entrepreneurship encompasses the study, construction, and development of theories about entrepreneurship, whereas educating entrepreneurship focuses on the development of entrepreneurial skills and motivation. We lack consistent data how the entrepreneurial courses impact students' willingness to 
engage in an entrepreneurial activity; moreover, how they help become successful, and what kind of learning content and processes should be encompassed. Empirical data demonstrate existing links between entrepreneurial education programmes and students' later involvement in entrepreneurial activities. Some results show that completion of one entrepreneurship course increases the likelihood of having entrepreneurial intention by 1.3 times (Dehghanpour Farashah, 2013). Entrepreneurship graduates are three times more likely to start their own business, three times more likely to be self-employed, have annual incomes 27 percent higher, own 62 percent more assets, and are more satisfied with their jobs (Charney \& Libecap, 2000; cited in Kassean et al., 2015). Ronkko and Lepisto (2014) referring to previous research state that entrepreneurial behaviour can be learnt. However, some research states that entrepreneurial programme should be a complex to make a direct impact on entrepreneurship motivation (Farhangmehr, Gonçalves, \& Sarmento, 2016). The knowledge of business management is an important but not sufficient factor for motivation to start entrepreneurship; competencies of communication in close relation with confidence are rather important.

The study performed by Karimi et al.'s (2016) emphasises the need to evaluate the complexity of entrepreneurship education which, on the one hand, strengthens students' intentions for being entrepreneurs and, on the other hand, education makes people more conscious and self-critical. The study of self-efficacy carried out by Piperopoulos and Dimov (2015) shows that the type of the taught course is important for entrepreneurial intentions. The results show that the nature of the course moderates the relationship between students' self-efficacy beliefs and entrepreneurial intentions; the relationship is negative in "theoretically oriented" and positive in "practically oriented" courses. Some research data have already demonstrated that students who engage in more entrepreneurship experiential learning activities report greater entrepreneur initiatives (Kassean, et al., 2015).

\section{Overview of Coexisting Conceptualisations for Entrepreneurship Education}

Entrepreneurial education is a significant part of a vast field dealing with innovative education. The main unifying element between innovative pedagogy and entrepreneurship is a "created value" (Maritz \& Donovan, 2015). Innovative pedagogy is more focused on the process of creation; entrepreneurship is more oriented to commercialisation dealing with risk and uncertainty, and finally business establishment. It is considered that the mission of entrepreneurship is to fill a gap of commercialisation or discover new possibilities in the process of innovation (Maritz \& Donovan, 2015). However, entrepreneurship itself is a very broad and vague field that lacks unified conceptualisation (Farhangmehr, Gonçalves, \& Sarmento, 2016; Maritz \& Donovan, 2015; Ronkko \& Lepisto, 2014; Dehghanpour Farashah, 2013). Schumpeter introduced the idea of innovation, by describing entrepreneurs as innovators who drive changes in the economy by serving new markets or creating new ways of doing things. However, according to Drucker's (2015) point of view, the core element of entrepreneurship is about discovering opportunities; therefore, entrepreneurship is not always linked to innovation.

Mathews (2012) draws our attention to transformative thinking, which is aimed at creation of a culture of innovations. Building a better vacuum cleaner is not the same as generating breakthrough ideas. We need to reinvent not just what we do, but how we think about it: "Don't think about better vacuum cleaners, think about cleaner floors". 
Rae (2003) points out that opportunity-centred learning should play rather wide role in entrepreneurial education compared to traditional education aimed at acquisition of skills and knowledge. Entrepreneurship is most of all related to uncertainties that lead to opportunities.

There are two specialised conceptualisations in the field of entrepreneurship: process or method based. Neck and colleagues $(2018,2014)$ conceptualise entrepreneurship as a method opposite to a process. Process is concentrated more on the "input" and "output"; distinctively, a method is more oriented to practice. Entrepreneurship is not enough to make input, we need creativity, and afterwards we can expect good results. It is obvious that successful entrepreneurs need to be competent in both method and process.

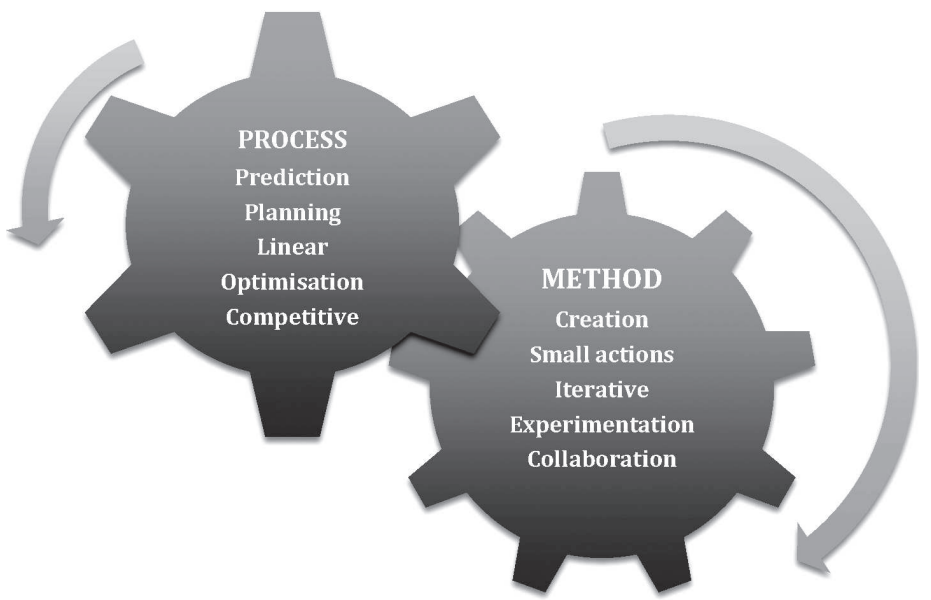

Figure 1. Coexisting conceptualisations of entrepreneurship (identification of factors based on Neck and colleagues, 2018, p. 39)

Neck, Greene, and Brush (2014) developed different games for students teaching them how to deal with opportunities and uncertainties. Moreover, game playing raises students' awareness of the difference between managerial and entrepreneurial thinking (ibid, p. 105).

\section{Conceptualisation of Entrepreneurship in the Context of Sustainable Development and Education}

A number of authors refer to entrepreneurship as the creation of new business, in particular start-ups. According to Greco and Jong (2017), sustainable entrepreneurship is rather oriented to transforming existing enterprises instead of creation of new ones. Such an approach allows applying the theories of entrepreneurship to not-for-profit organisations (e.g., social entrepreneurship, ecopreneurship). Together, established organisations and start-ups can initiate and accomplish sustainable development, working in symbiosis in a co-creation process, depending on each other for mutual success. Kardos (2012) notes that a sustainability approach not only contributes to the sustainable development of the organisation itself but also creates an increasingly large contribution of the organisation to sustainable development of the market and society as a whole. 
Sustainable development is to find an optimal interaction of economic, human, environmental and technological systems. Therefore, sustainable entrepreneurship is a wide concept encompassing human, technological, and business factors: Balancing economic health (profit), social equity (people) and environmental resilience (planet) through entrepreneurial behaviour is what identifies a sustainable entrepreneur (Hockerts \& Wüstenhagen, 2010; cited in Greco \& Jong, 2017). According to Kardos (2012), we talk about sustainopreneurship and sustainability entrepreneurship, "meaning to use creative business organising to solve problems related to the sustainability agenda to create social and environmental sustainability as a strategic objective purpose" (p. 1031).

Conceptual level brings a convincing relationship between entrepreneurship and sustainable development. Recently, we have witnessed a growing number of empirical evidence as well (Kardos, 2012; Stefanescu \& On, 2012). Research by Kardos (2012) provides meaningful evidence: "the emergence and growth of innovative firms are crucial for structural change towards sustainable development" (p. 1034). However, measurement of such kind of relationship remains difficult, as there is no method agreed upon, we have to deal with multidimensional concepts, and there are many differences among countries in fixing indicators for sustainability due to entrepreneurship.

Education is a factor that could help integrate all different aspects; however, some experts criticise efforts of education to fulfil demands of economic development: "Teacher education reform in the 21 st century can be criticised for being almost exclusively oriented toward principles of economic growth, effectiveness, and competitiveness at the expense of other important aims of education in the global era" (Rönnström, 2013, p. 194). Despite certain criticism, there is a growing stream for changes in education that foster entrepreneurship at both national and global scales. Entrepreneurship as a global phenomenon unfolds through growing numbers in talent migration.

\section{Methodology}

We have chosen a natural group interview method as a unique one for supporting our research spirit and aims. Group interview is often confused with focus group discussion (Fontana \& Frey, 2003). We give priority to a group interview due to the following reasons. Group interview is conducted as a systemic unstructured questioning of several individuals simultaneously in different settings of university environment (i.e., one in a lab, one in a discussion room, and one in an administration office). Group interviews are helpful to follow naturalistic inquiry spirit; they not only give unique data for researchers, but also are stimulating for respondents, aiding recall. For interview there were chosen groups within the 'natural' context of the research setting. Because of being embedded in ongoing life, interviews with natural groups often do not follow the controlled format and procedures compared to focus groups interviews. The natural group interviews provide a forum where different views could be freely expressed in a natural setting.

Three separate group interview were conducted as follows: four university students who have developed start-up projects in recent five years, three university teachers who give supervision for the students' idea development, and four administration specialists who provide management support for projects. Students sample consists of four males, average age 27 years; three students are from the field of technologies, and one student from business management. Right now three of them continue working at the University. One of these students continue working with successful start-up development. University 
teachers sample: two men, one woman, all they are from the field of technologies, average age 56 years. Administrators sample: three women, average age 43 years. With each group have been held one interview session.

As all participants of group interview already have experience in participating in entrepreneurial activities, the core questions for raising discussion were as follows: what is motivation for being involved to entrepreneurial activities? What kind of support do you need? What is the role of university teacher? What impact is form the education? What is the role of people in university administration? What administrators have learned from early experience of giving support for entrepreneurial activities? What have you learned from early entrepreneurial activities?

Interpretative analysis was applied for group interview materials. In addition, tacit academic experience of article authors has been involved, which facilitates the research process through recording observations, thoughts and questions as they set in the diary for later use to stimulate reflective thinking.

\section{Research Results on Early Entrepreneurship Experience at University}

According to group interviews, opportunities are the main point to engage in entrepreneurial activities. It is consistent with a general situation; moreover, Degeorge and colleagues (2011) note, it is a pervasive theme in entrepreneurship research articles. Students talk about an opportunity as something different from both what they are used to and what should be tested. In a certain sense, an opportunity is seen as a subjective experience and an experiment with new ideas. Only to a limited extent, students associate opportunities with the creation of new knowledge. On the contrary, teachers perceive the opportunity as an objective point through a rational-analytical approach. Discussions and consultations are the space where students and teachers' different approaches towards an opportunity interact with the discovery of new possibilities.

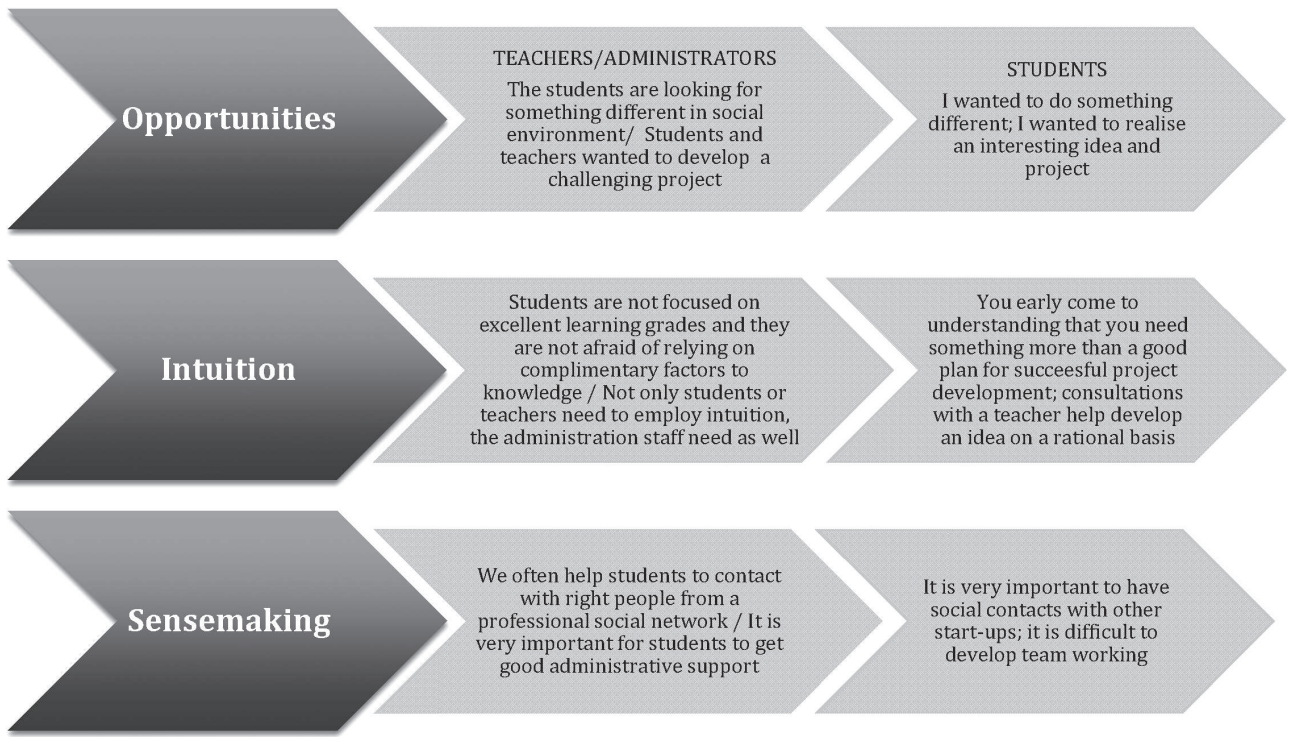

Figure 2. Interpretative analysis: characteristic notices of group interviews 
Our respondents talk about highly complex situations, which are challenging to handle following the foreseen project plan. Eventually, they all increasingly employ intuition. It is very important to help students to recognise intuition through strengthening analytical reflections with the teacher's supervision. According to Shapiro and Spence (1997), intuition as a complex and unconscious process induces a feeling of certainty; however, it lacks rational reasoning. It is difficult to evaluate the effects of intuition before the results become apparent. Here, decisions are taken instantaneously, in the heart of action, without recurring to conscious analytical reflection; they are intuitive as opposed to rational reactions (cited in Degeorge, 2011). To make an educational impact, it is important to know different aspects of intuition, following Atkinson and Claxton (2001):

- expertise - the unreflective execution of intricate skilled performance;

- implicit learning - the acquisition of such expertise by non-conscious or nonconceptual means;

- judgement - making accurate decisions and categorisations, being able to explain or justify them;

- sensitivity - a heightened attentiveness, both conscious and non-conscious to details and situation;

- creativity - the use of incubation and reverie to enhance problem-solving;

- rumination - the process of "chewing the cud" of experience in order to extract its meanings and its implications.

Atkinson and Claxton (2001) see a great challenge in enlarging the education of intuition in business management programmes.

It seems that entrepreneurship is a highly chaotic and unpredictable activity. However, it has to seek for a certain degree of order to "normalize unpredictability" (Walls, 2017). Sensemaking is the process of creating situational awareness and understanding in situations of high complexity or uncertainty in order to make decisions. Sensemaking describes the negotiation and creation of meaning, or understanding. Weick (1993) argues, "The basic idea of sensemaking is that reality is an ongoing accomplishment that emerges from efforts to create order and make retrospective sense of what occurs" (p. 635). Students starting entrepreneurial activities with a driving force of opportunities face a great challenge to manage the complexity. Sensemaking is a helpful approach for both teachers and students to develop a certain order in a highly complex system. Students report a great need for help in communication and teamwork development that is important for sensemaking development. In Madsbjerg's (2017) conceptualisation, knowledge is an important factor for sensemaking. Hajizadeh and Zali (2016) analysed the impact of prior knowledge on entrepreneurial activities and concluded that it was an important issue especially in technologies; however, it could not be overestimated. Madsbjerg (2017) draws attention to knowledge within a social context:

- subjective knowledge (the world of personal opinions and feelings, a reflection of our inner lives);

- shared knowledge (our public and cultural knowledge; it involves sensitivity to our various social structures by capturing nuances such as mood);

- sensory knowledge (to some extent, it can be equated to "sixth sense").

In our research, teachers help students to connect objective knowledge to a social context. However, teachers admit that each case is individual and they lack generalised experience for such a practice. 


\section{Discussion}

Entrepreneurship signifies a new type of economy and a different trend for human development: "homo economicus provides room for homo entreprenaurus" (Costa \& Saraiva, 2012, p. 588). Post-school entrepreneurship education is considered the fifth important factor out of twelve in the entrepreneurship ecosystem (Neck et al., 2018). This implies the role of university as a key driver, particularly at the early stages of entrepreneurship development.

In many different studies, evidence-based data prove that the role of education is very important for entrepreneurship. However, there is a lack of consistent theoretical background for systemic estimation of the impact which education can accomplish for entrepreneurial activities. Education is mainly considered a fostering motivation for business-oriented entrepreneurship. Educational programmes are a valuable prerequisite for entrepreneurship when they are based on the integration of complex factors encompassing theoretical knowledge, competence development, and confidence fostering. Growing attention to sustainability entrepreneurship is being witnessed as well. However, we do not have a clear answer if the same models of education could be equally effective for both business-oriented and sustainability entrepreneurship. Our research results are consistent with aforementioned notion that needs for entrepreneurial education and could not be framed within one particular educational model.

Group interview method was really useful for understanding the complex behaviour of entrepreneurs without imposing any a priori categorisation and for developing unique insights into the human experience. Our research has its limitations due to a small size of the sample. We hope this opens the perspective to new and challenging research. We suggest our conceptualisation as a unique base for further research with an extended sample.

\section{Conclusions}

There are two coexisting paradigms of method and process in relation to entrepreneurial education. The approach of method is more suitable for the educational context as it focuses on creativity, idea development, small actions, experimentation; the paradigm of process is suitable for enterprise and business plan development. However, they cannot be opposed as we lack empirical data about their difference of impact that can be caused while applying aforementioned paradigms on experiment basis. Our research demonstrates that in early entrepreneurship experience we can recognise more factors with distinctive features of method approach.

Our research shows that students' motivation for entrepreneurship when they do not have prior education on the issue is strongly based on the opportunities. When they face the complexity of reality, they need more than separate competences or knowledge; moreover, they need them as an integrated phenomenon. We see sensemaking as the effective approach to respond to the constantly changing environment with the emergence of sustainable entrepreneurship.

Our research implies that it is not difficult to start entrepreneurial activity without a special education programme. However, it is difficult to develop it and finalise successfully. Our experience shows that only one out of four entrepreneurial projects succeeded without special entrepreneurial education. Moreover, the existing research demonstrates that education can help have a bigger number of entrepreneurship initiatives. Therefore, 
we can state that there is a clear need for special entrepreneurial education at university that would help have more initial projects, encourage to start, and also to succeed in the future. Development of entrepreneurship initiatives as corporate projects within university fosters in young people's mind the understanding of sustainable development and its meaningfulness.

\section{References}

Atkinson, T., \& Claxton, G. (eds.). (2001). The intuitive practitioner: On the value of not knowing what one is doing. Open University Press.

Costa, A. M., \& Saraiva, L. A. (2012). Hegemonic discourse on entrepreneurship as an ideological mechanism for the reproduction of capital. Organization, 19(5), 587614.

Cope, J. (2011). Entrepreneurial learning from failure: An interpretative phenomenological analysis. Journal of Business Venturing, 26, 604-623.

Degeorge, J.-M., Fayolle, A., \& Randeson, K. R. (2011). Individual commitment to entrepreneurial opportunities within firms: Does intuition-based behavior matter? Submission for European Summer University.

Dehghanpour Farashah, A. (2013). The process of impact of entrepreneurship education and training on entrepreneurship perception and intention. Study of educational system of Iran. Education + Training, 55 (8/9), 868-885.

Dew, N. (2009). Serendipity in entrepreneurship. Organization Studies, 30(7), 735-753.

Druker, P. (2015). Innovation and entrepreneurship. Practice and principles. London: Routledge.

Dutta, D. K., Li, J., \& Merenda, M. (2011). Fostering entrepreneurship: impact of specialization and diversity in education. International Entrepreneurship Management Journal, 7(2), 163-179.

Farhangmehr, M., Gonçalves, P., \& Sarmento, M. (2016). Predicting entrepreneurial motivation among university students. The role of entrepreneurship education. Education + Training, 58(7/8), 861-881.

Fontana, A., \& Frey, J. H. (2003). The interview: From structured questions to negotiated text. In N. K. Denzin \& Y. S. Lincoln (Eds.), Collecting and interpreting qualitative materials (2nd ed., pp. 645-672). London: Sage.

Hajizadeh, A., \& Zali, M. (2016). Prior knowledge, cognitive characteristics and opportunity recognition. Journal of Entrepreneurial Behavior \& Research, 22(1), 63-83.

Hall, J. K., Daneke, G. A., \& Lenox, M. J. (2012). Sustainable development and entrepreneurship: Past contributions and future directions. Journal of Business Venturing, 25 (2010), 439-448.

Ebner, A. (2005). Entrepreneurship and economic development. From classical political economy to economic sociology. Journal of Economic Studies, 32(3), 256-274.

Gergen, K. J. (2015). An invitation to social construction (3rd ed.). Thousand Oaks, CA: Sage.

Greco, A., \& Jong, G. (2017). Sustainable entrepreneurship: Definitions, themes, and research gaps. University of Groningen. Working Paper series. Available at https://www.rug.nl/cf/pdfs/wps6_angela.pdf

Karimi, S., Biemans, H. J. A., Lans, T., Chizari, M., \& Mulder, M. (2016). The impact of entrepreneurship education: A study of Iranian students' entrepreneurial 
intentions and opportunity identification. Journal of Small Business Management, 54(1), 187-209. doi: 10.1111/jsbm.12137.

Kardos, M. (2012). The relationship between entrepreneurship, innovation and sustainable development. Research on European Union countries. Procedia Economics and Finance, 3, 1030-1035.

Kassean, H., Vanevenhoven, J., Liguori, E., \& Winkel, D. E. (2015). Entrepreneurship education: A need for reflection, real-world experience and action. International Journal of Entrepreneurial Behavior \& Research, 21(5), 690-708.

Kraus, S. Meier, F., \& Niemand, T. (2016). Experimental methods in entrepreneurship research: The status quo. International Journal of Entrepreneurial Behavior \& Research, 22(6), 958-983. doi: 10.1108/IJEBR-05-2016-0135

Laukkanen, M. (2000). Exploring alternative approaches in high-level entrepreneurship education: Creating micromechanisms for endogenous regional growth. Entrepreneurship and Regional Development, 12 (1), 25-47.

Linden, J. (2018). Entrepreneurship education for a sustainable future. Discourse and Communication for Sustainable Education, 9 (1), 115-127.

Madsjerberg, Ch. (2017). Sensemaking: The Power of the Humanities in the age of the algorithm. Hachette books.

Maritz, A., \& Donovan, J. (2015). Entrepreneurship and innovation. Setting an agenda for greater discipline contextualization. Education + Training, 57(1), 74-87.

Mathews, B. (2012). Think like a startup: A white paper to inspire library entrepreneurialism. Available at https://vtechworks.lib.vt.edu/bitstream/handle/10919/18649/ Think\%20like\%20a\%20STARTUP.pdf? sequence=1\&isAllowed=y

Neck, H. M., \& Greene, P. (2011). Entrepreneurship education: Known worlds and new frontiers. Journal of Small Business Management, 49(1), 55-70.

Neck, H. M., Neck Ch. P., \& Murray, E. L. (2018). Entrepreneurship: The practice and mindset (1st ed.). London: Sage.

Neck, H. M., Greene P. G., \& Brush C. G. (2014). Teaching entrepreneurship: A practicebased approach. Cheltenham: Edward Elgar Publishing.

Nielsen, S. L., \& Gartner, W. B. (2017). Am I a student and/or entrepreneur? Multiple identities in student entrepreneurship. Education + Training, 59(2), 135-154.

Peters, M. A., \& Besley, T. (2008). Academic entrepreneurship and the creative economy. Thesis Eleven, 94, 88-105.

Piperopoulos, P., \& Dimov, D. (2015). Burst bubbles or build steam? Entrepreneurship education, entrepreneurial self-efficacy, and entrepreneurial intentions. Journal of Small Business Management, 53(4), 970-985. doi: 10.1111/jsbm.12116.

Rae, D. (2003). Opportunity centered learning: An innovation in enterprise education? Education + Training, 45(8/9), 542-549.

Robinson, S., Neergaard, H., Tanggaard, L., \& Krueger, N. F. (2016). New horizons in entrepreneurship education: From teacher-led to student-centered learning. Education + Training, 58(7/8), 661-683.

Rönkkö, M. L., \& Lepistö, J. (2015). Finnish student teachers' critical conceptions of entrepreneurship education. Journal of Enterprising Communities: People and Places in the Global Economy, 9(1), 61-75.

Rönnström, N. (2013). From globalist to cosmopolitan learning: On the reflexive modernization of teacher education. Ethics \& Global Politics, 5(4), 193-216. doi: 10.3402/ egp.v5i4.20305. 
Salite, I., Drelinga, E., Iliško, Dz., Oḷehnoviča, E., \& Zariņa, S. (2016). Sustainability from the transdisciplinary perspective: An action research strategy for continuing education program development. Journal of Teacher Education for Sustainability, $18(2), 135-152$.

Shapiro, S., \& Spence, M. T. (1997). Managerial intuition: A conceptual and operational framework. Business Horizon, 40(1), 63-68.

Stefanescu, D., \& On, A. (2012). Entrepreneurship and sustainable development in European countries before and during the international crisis. Procedia - Social and Behavioral Sciences, 58, 889-898.

Walls, J. H. (2017). Sensemaking and school failure: Lessons from two cases. Journal of Organizational Theory in Education, 2, 1-26.

Weick, K. E. (1995). Sensemaking in organizations. Thousand Oaks, CA: Sage.

Correspondence concerning this paper should be addressed to Asta Valackiene, Nemuno str. No. 33, Panevežys LT-37164, Lithuania. Email: asta.valackiene@ktu.lt 